\title{
The Academic Library Looks at Union Lists
}

Computer-based serials listings are rapidly becoming a popular method by which libraries make their serial holdings available. In addition, there is increasing pressure on libraries to participate in serial union lists. Because expenditure of staff time is an important factor in such participation, various kinds of union lists are examined in order to determine the most effective and least costly ways in which a library can have a list and attendant benefits for its own purpose, and also join in cooperative efforts.

B Y NOW, MANY LIBRARIES have either produced or are aware of the advantages of computer-based lists of serials for local needs. In addition, libraries realize that their participation will be requested in union list projects which are being planned on both regional and national levels. It is the purpose of this article to consider whether a library can satisfy the demands placed upon it for cooperative ventures and at the same time meet its individual needs. Three major developments have prompted such a discussion: (1) the proliferation of regional lists of serials; (2) the development of a program for a national serials data bank; and (3) the current state of computer technology as it relates to union lists.

\section{The Local LisT}

It is neither difficult nor uncommon for an individual library to produce a computerized list of serials. Most libraries will feel that the time and expense are worthwhile when compared

Miss Ellsworth is serials librarian at Wilbur Cross Library, University of Connecticut, Storrs, Connecticut. with the limited products of a wholly manual operation. The most obvious advantages of using a computer to perform this operation are the ease of producing multiple copies and the possibility of continuous updating. In addition, the data can be manipulated to produce lists by subject, vendor, or lists of incomplete files. ${ }^{1}$ The serials lists thus become extremely useful for both the staff and clientele of the institution. Such a list can be distributed to other libraries who may wish to have it, but these individual lists are of limited use for the purpose of interlibrary loan. Producing a list at the local level allows the library considerable freedom in choosing the form of entry and type of programming best suited to its needs.

\section{The UNION List}

Union lists of serials serve the dual purpose of providing bibliographic information as well as identifying locations where titles can be found. ${ }^{2}$ If their growing number is any indication, union lists are much needed by libraries. It is useful at this point to examine the kinds of lists in which one can participate, their possible cost, advantage, and problems for the large research library. 


\section{The State List}

The state list serves the purpose of making known the resources of its public, special, and academic libraries. In such a list, therefore, similarity of collections is not the motivating factor. It has been pointed out that smaller libraries in the state are more willing to cooperate in such a list since they will have less to report and will also benefit more because the burden of interlibrary loan is placed on the large library. ${ }^{3}$ All large academic libraries in the state need to participate in order to ensure mutual benefits. Although both small and special libraries often have titles which the academic library might need, the library has to consider whether the cost of participation in terms of staff time matches the usefulness of the state list for the academic library.

\section{Regional Lists}

Regional lists can include any number of libraries in various groupings. The groups can be arranged by similarity of collections and goals, by size of library, etc. Regional lists can theoretically provide a greater number of titles for interlibrary loan purposes than a state list. In addition, such a grouping can be the basis for cooperative acquisitions and storage and weeding programs. In order to be effective, however, the group must agree on common goals such as form of entry and the kinds and amount of titles which will be included. The costs for these activities should be shared so as to produce savings for all.

\section{Special Lists}

An example of this kind is ACCESSthe list of scientific serials prepared under the jurisdiction of the American Chemical Society. A list of this type is of importance primarily to a defined group of people. The cost of participat- ing in such a list must be measured in terms of the need it fulfills for the individual library.

\section{NATional Lists}

\section{The Union List of Serials and New} Serials Titles provide the widest general coverage of location and bibliographical description now presently available. However, not all locations for a title are given, a factor which led in the past to the development of lists at the local and regional level. Currently in the development stage is the National Serials Data Program. The announcements for this project indicate that it will offer a wide variety of services, such as information on holdings and location for all serials, publishing and dissemination of special union lists by categories, and machinereadable data for local processing. ${ }^{4}$ While this program seems admirable in its definition and scope, it will probably be some time before it is fully operational. The pilot project is dealing now with medical and scientific serials, although ultimately it will be expanded into other disciplines. ${ }^{5}$ Operating within the national framework would provide certain advantages: (1) greater coverage of titles; (2) standardization (of format); and (3) greater access to government programs and funds.

\section{Cost of Participation}

The cost of participating in union list projects can be measured in the amount of staff time used in the reporting of holdings and in the subsequent updating procedures. Although a library may be willing to cooperate in union list projects, it must seriously consider the economics of filling out numerous checking editions and continuously reporting to diverse agencies. If there is any increasing demand for this kind of participation, a library would either have to hire additional personnel or di- 
vert present staff from the daily operation which most libraries can ill-afford. Sending a locally produced tape is usually not feasible unless it is compatible with the master tape of the produceragency. If the library's own list can be used as the basis of a union list, this is of course desirable, but cannot be expected. Given this situation, the following actions are possible: (1) the library can develop its own list and ignore other projects; (2) the library can develop its own list and participate in a few selected union lists which it feels it cannot ignore; (3) the library can set up guidelines for participation in other projects and hopefully develop its own list in conjunction with one of these projects; and (4) the library can participate in all union list projects.

There is no question but that there is some cost involved when a library develops a list on its own. Included is the staff time needed to prepare the records; the hiring or training of computer personnel; the expense of running a computer; and supplies. If the library can obtain the information and services it needs in another way, this kind of individual expenditure would not be necessary. It is also true that a library which has a large interlibrary loan operation will find it easier with a comprehensive union list at its disposal. The third alternative is, therefore, probably the most feasible.

If a library has need of setting up guidelines for participation, one or more of the following criteria should influence the decision: (1) evenly balanced sharing of interlibrary loan requests; (2) the possibility of shared acquisition programs; (3) the possibility of having lists produced as a substitute for local records (vendor lists, ceased titles); (4) the availability of lists of the individual library holdings by subject to satisfy the demands of local users; (5) a format which can be uti- lized by different libraries (i.e., sufficient cross-references for variant forms of entry); and (6) representation in the decision-making process.

The National Serials Data Program shows the most promise since it would lead to standardization, fulfill most of the criteria mentioned above, and greatly reduce duplications effort. Most of this will be accomplished by utilizing computer technology. A recent article has pointed out, however, that advances in automation have led thus far to an increase in regional lists rather than to processing at the national level. ${ }^{6}$ If the national program is capable of providing services for both large and small libraries in the near future, it would seem wasteful to devote so much money and effort to local solutions.

However, the increasing demands placed on libraries by their clientele and the need for interlibrary loan information have tended to favor the development of the regional plan. Many of the regional lists now being developed have been planned so they can be adapted by other library systems. Such lists as the Union Catalog of Medical Periodicals (New York) and, in particular, the Intermountain Union List of Serials have no limitation to their capacity or flexibility. ${ }^{7}$

A proposal for a regional list in lieu of a state/national/or local list at this time would have the following advantages: (1) utilization of work (programs, tapes, etc.) done by other libraries; (2) a central processing area, i.e., several libraries can absorb the cost of processing and editing the data; (3) use of a computer and computer personnel primarily engaged in library related activities-the cost shared by participating libraries; (4) a larger data base than could be provided by an individual library or by the libraries within a single state; (5) interlibrary loan cooperation because of geographic prox- 
imity; and (6) possibility for cooperative acquisition plans to offset the rising cost of serials.

In order for the center to be effective, the following requirements would have to be fulfilled: (1) defining a group of libraries which would be willing to cooperate and would benefit equally from the project; (2) utilization of programs compatible with the MARC/COBOL format of the Library of Congress; (3) possibility of on-line interrogation to save time and transmit machine-readable information; (4) ability of the program to add or suppress certain kinds of information to allow for local variation; (5) production of lists by subject categories; and (6) frequent updating. ${ }^{8}$

A regional plan developed along these lines is NELINET, the joint venture of the five New England State University Libraries, which has already produced a shared cataloging program. The program utilizes the MARC II format and can provide individual services for participating libraries. A regional center can be established as a separate entity or can be located at a designated library, the participants sharing jointly in the cost of maintaining staff and equipment. A study of the costs and relative merits of the type of center would have to be made before any decision could be reached.

In summary, the adoption of a regional plan at this time would include greater benefits for the individual library by expanding the resources available to it. Current computer technology can provide the flexibility needed to make the computer product useful for individual participants. Any proposal for a regional union list, whether on state or type-of-library level should consider the plans underway at the national level. In this way the regional center can act as a link in the network when the national program is operable by being able both to accept from and communicate information to the national center. If such steps as those listed above are taken, regional plans need not be looked at as an attempt to deflect energy from efforts being made at the national level, but as a positive step toward greater cooperation and communication. At the same time, needed services will be provided to the faculty, students, and staff at the library.

A library can only decide for itself to what extent it can cooperate with requests for union list participation, but a library which is involved in a working, cooperative project can afford to be more discriminating about its involvements.

\section{REFERENCES}

1. Jacqueline W. Felter and Djoeng S. Tjoeng, "A Computer System for a Union Catalog: Themes and Variations," Medical Library Association Bulletin 53:163-69 (April 1965).

2. Harry Dewey, "The National Union List of Serials: Weaknesses and a Proposal," $\mathrm{Li}$ brary Resources \& Technical Services 2: 225-38 (Fall 1968).

3. Kenneth D. Olson, "Union Lists and the Public Record of Serials," Special Libraries 61:15-20 (Jan. 1970).

4. William H. Huff, "The Acquisition of Serial Publications," Library Trends 18:314 (from a working paper prepared by Elaine W.
Woods, National Serials Data Program, Phase I).

5. Association of Research Libraries, "Present Status of the National Serials Pilot Project" (Memorandum), 13 Jan. 1969, p.3.

6. Scott Adams, "Progress Toward a National Serials Data System," Library Trends 18: 512 (April 1970).

7. Felter, “A Computer System," p.177.

8. William R. Nugent, NELINET; the New England Library Information Network, Paper presented at the International Federation for Information Processing, Edinburgh, 1968 (Cambridge, Mass.: Inforonics), unpaged. 